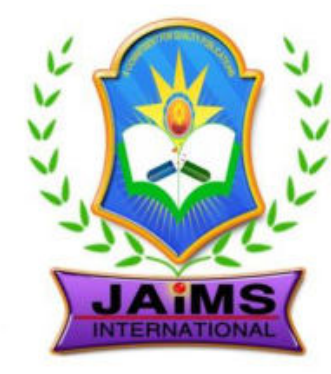

ISSN 2456-3110

Vol $5 \cdot$ Issue 1

Jan-Feb 2020

Journal of

Ayurveda and Integrated Medical Sciences

www.jaims.in

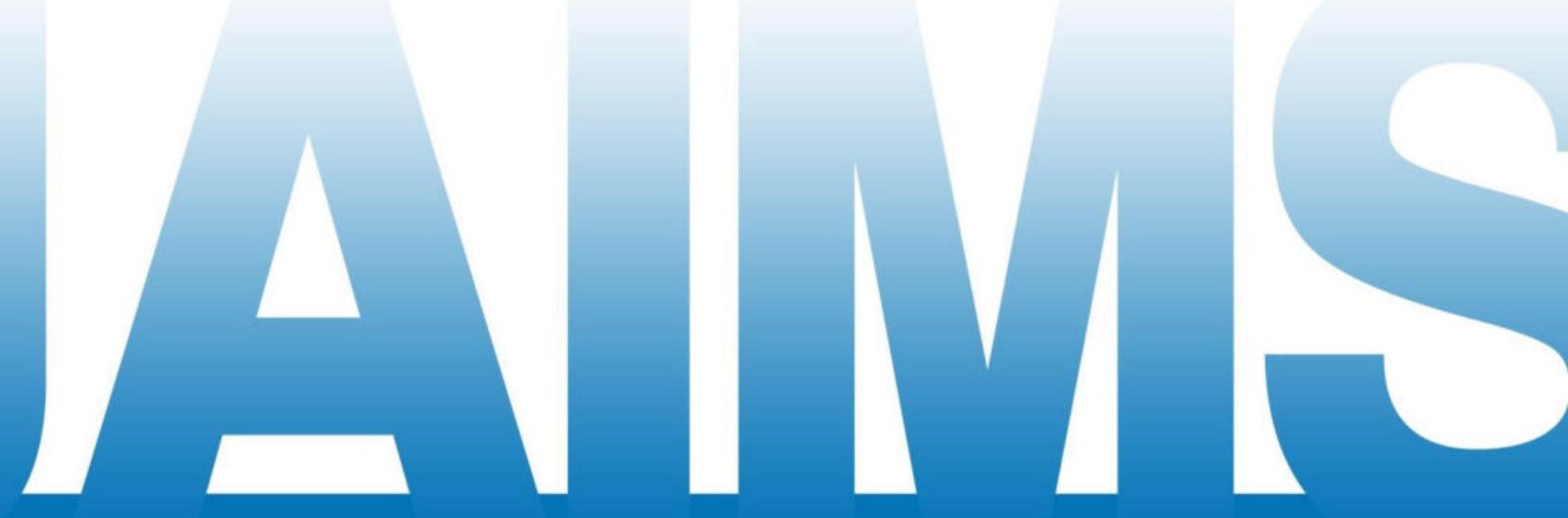

An International Journal for Researches in Ayurveda and Allied Sciences

\title{
Charaka
}




\section{A study of Radiological changes in Janu Sandhi}

\section{in Amavata}

Wasu Isha Pradeep ${ }^{1}$, Choudhari Vinod Mahadevrao ${ }^{2}$

${ }^{1}$ Post Graduate Scholar, ${ }^{2}$ Professor \& HOD., Dept. of Rachana Sharir, Shri Ayurved Mahavidyalaya, Nagpur, Maharashtra, INDIA.

\section{A B S TR A C T}

\begin{abstract}
Aim - To study radiological changes in Janu Sandhi due to Amavata. Objectives - 1) To study about Janu Sandhi and Knee Joint, 2) To study about Amavata and Rheumatoid Arthritis. Observation - The 7 diagnostic criteria according to American College of Rheumatology, epidemiology and genetics, radiological evaluation is one of them, for knee joint - soft tissue swelling, periarticular osteoporosis, joint space reduction, osteophytes, dislocation of joints, secondary eburnation, pseudocytes, periosteal new bone formation, bone erosion is seen. In radiological changes, soft tissue swelling, joint space reduction and osteophytes is found in $80 \%$ patients, periarticular osteoporosis is found in almost $90 \%$ patient. Conclusion - Female are more prone to radiological changes in knee joint affected by Amavata than male. Also age group of 41-50 yrs are more affected and Vata-Kapha Dehaj Prakruti people has more radiological changes. This is helpful to find out the extent of progression of disease in stages of disease and treatment of disease.
\end{abstract}

Key words: Janu Sandhi, Amavata, Knee Joint, Rheumatoid Arthritis, Radiological changes.

\section{INTRODUCTION}

In the Science of medicine detailed knowledge of the body, its parts and entities is important for well being of human being, so the knowledge of Sharira is admirable. Acharya Sushruta has described Sandhi (Joint) in Sharir Sthan in "Sharirsankhya Vyakaranam Shariram Adhyay", mentioning 210 Sandhis in human body. The place where two body parts join with the help of Shleshma is called as Sandhi (Joint). ${ }^{[1]}$

Acharya Sushruta has defined the term Sandhi as a point where any similar type of two structures meet

\section{Address for correspondence: \\ Dr. Wasu Isha Pradeep \\ Post Graduate Scholar, Dept. of Rachana Sharir, Shri Ayurved \\ Mahavidyalaya, Nagpur, Maharashtra, INDIA. \\ E-mail: isha4md@gmail.com \\ Submission Date: 05/01/2020 \\ Accepted Date: 16/02/2020}

Quick Response Code

each other like, Asthisandhi (Bony Joint), Sira Sandhi (Venous Joint) or Peshi Sandhi (Muscular Joint). ${ }^{[2]}$ Dealing with Asthi Sandhi, are of two types Cheshtawant Sandhi, Sthir Sandhi. Also, there is division of Sandhi's into 8 types, ${ }^{[3]}$ Janu Sandhi (Knee Joint) comes under Kora Sandhi. The Knee joint is the largest, more complex and weight bearing joint of the body. Many diseases are found in Janu Sandhi. "Amavata" is one of them. In the developing and mechanical world the lifestyle is too much busy and speedy. Change in Ahar, Vihar, Dincharya, Ritucharya results in Rasa-Raktadi Srotodushti, Dhatudushti, immunocompression etc. So human being is more susceptible to diseases. Amavata is one of the diseases which occurs more often now a days due to above said factors.

It is only in Madhava Nidan the disease "Amavata" was described first as an independent disease. It is a disease included in Madhyam Rogamarga, as it affects Sandhis. Though Ama and Vata are the predominant pathogenic factors but the disease represents tridoshic vitiation. It was observed that most of the signs and symptoms of "Amavata" as 
described in Madhava Nidan are quite similar to that of "Rheumatoid Arthritis". According to Acharya Madhavkara, the disease is mostly found in Hasta Pada Sandhi, Shiro Sandhi, Gulpha Sandhi, Trika Sandhi, Janu Sandhi, Janu Sandhi and Uru Sandhi. There is Saruja Shotha over these Sandhis. The symptoms seen in Amavata are Angamarda, Aruchi, Trushna, Aalasya, Gaurava, Jwara, Apaka, and

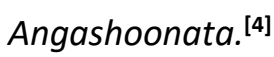

In Rheumatoid Arthritis also M.C.P. (Metacarpophalangeal) joints, P.I.P (Proximal Inter Phalangeal) joints, wrist joints, elbow joints, knee joints, ankle joints and M.T.P. (Metatarso-Phalangeal) joints are mainly affected. Janu Sandhi is also affected. Lot of study has been done so far on most of the joints in Amavata. Now a day we find many patients suffering by Amavata with involvement of Janu Sandhi but its study remains neglected from many aspects. The radiological aspect is the most neglected, as far as involvement of Janu Sandhi is concerned. Therefore, with the help of radiological technique (X-ray), the changes are found in Janu Sandhi in patient suffering from Amavata is presented here.

\section{AIM}

To study radiological changes in Janu Sandhi due to Amavata

\section{Objectives}

1. To study about Janu Sandhi and Knee Joint.

2. To study about Amavata and Rheumatoid Arthritis.

\section{Material and Methods}

Materials - All Ayurvedic and contemperory references about Janu Sandhi (Knee Joint), Amavata (Rheumatoid Arthritis) are collected from respective texts.

Methods - Radiological investigation i.e. X-rays of patients suffering from Amavata (RA) of Janu Sandhi were observed.
Prospective of Janu Sandhi and Knee Joint

\section{Janu Sandhi}

Acharya Charak has described that one bone covers the Janu anteriorly. This bone is called as "Janukapalika". ${ }^{[5]}$ Acharya Vaghbhata has described Janu in Kapalasthi, ${ }^{[6]}$ which is considered as Patella in modern science. Acharya Dalhan has considered two Sandhi in a Janu region by describing Janupari and Janwadha Sandhi (Janunoadha Sandhi), this is considered as the Proximal Tibiofibular Joint. Hence, Janu Sandhi is the main Sandhi in the Janu region and it is the articulation between the Urwasthi (Femur) and Janghasthi (Tibia). Two Janvasthi are described in Charaka Samhita ${ }^{[7]}$ and Kashyap Samhita ${ }^{[8]}$ as well.

\section{Knee Joint}

The Knee joint is the largest and more complex joint of the body. The complexity is due to fusion of three joint in one formed by fusion of lateral femorotibial, medial femorotibial and femoropatellar joints. It is a compound synovial joint, incorporating two condylar joints between the condyles of the femur and tibia, one saddle joint between the femur and the patella. The knee joint is formed by femur lower end (lateral condyle, medial condyle, intercondylar notch), patella, tibia upper end (medial condyle, lateral condyle, intercondylar area, tibial tuberosity) and fibula. Knee joint is mainly comprises of 11 ligaments and 13 busrae is seen.

\section{Amavata}

As the name indicate, the two predominant pathological factors i.e. Ama and Vata. "Ama" is undigested and vitiated Rasa Dhatu due to improper functioning of Agni in Amashaya producing Sama Dosha, Dhatu, Mala. ${ }^{[9]}$ Vata the another major component of Amavata, pain and restricted movement of joints are due to Vata specially Vyan and Saman Vayu, which are the cardinal features of the disease. When Ama is formed in Amashaya it causes Margavarodha leading to vitiation of Vata, which in turn propel the Ama throughout the body via Rasa Dhatu, then becomes seated in Shleshma Sthana especially in the Sandhis leading to Stabhdata of body 
and produce various symptoms of Amavata. The knee involvement becomes easily detectable on plain $X$ rays with reduction of the joint space, erosions, osteopenia and deformities setting in.

\section{Rheumatoid Arthritis}

Rheumatoid Arthritis is a chronic, immune inflammatory, multisystem disease of unknown cause that affects mainly synovial joints with possibility of extra-articular manifestations. The characteristic feature of RA is persistent inflammatory synovitis, usually involving peripheral joints in a symmetric distribution. Generally, the joint involvement is bilateral, peripheral, symmetrical, characterized by early morning stiffness with a positive rheumatoid factor in approximately $75 \%$ of patients. These are involved very commonly in RA and detected easily. Typical discolouration occurs at the base of the foot laterally and is known as crescent sign. The knee involvement becomes easily detectable on plain $X$ rays with reduction of the joint space, erosions, osteopenia and deformities setting in.

Radiographic Evaluation ${ }^{[10],[11]}$

The 7 diagnostic criteria according to American College of Rheumatology, radiology was one amongst them. Early in the disease, roentenograms (X-rays) of the affected joints reveal only evidence of soft tissue swelling and joint effusion. As the disease progresses, abnormalities become more pronounced. Periarticular osteoporosis may become apparent within weeks of onset. This periarticular osteoporosis is believed to be in part due to a combination of synovial hyperaemia and disuse due to pain. Loss of articular cartilage and erosions develop after months of sustained activity. Destruction of articular cartilage by pannus leads to joint space narrowing. Further destruction leads to erosions which occur initially at the joint margins. Extensive erosion may disrupt the joint surfaces.

Soft tissue changes of RA in the knee include chronic intracapsular effusion. The fluid tends to accumulate in the suprapatellar pouch. On lateral view, this may be seen as fullness in the suprapatellar area with displacement of the fat lines away from the femur. In anteroposterior view, a curved radiolucent line lateral or medial to the distal femoral shaft in the suprapatellar area indicates this condition. Massive distention of the popliteal bursa may be evaluated in some cases. Synovial fluid may leak into surrounding tissues. Osteoporosis develops, because the matrix is reduced in quantity there is necessarily a reduction in calcium content. The hallmark of RA in the knee joint space narrowing of all three compartment: the medial, lateral, and retropatellar (Joint space narrowing - Joint space is a misnomer as it is not a space at all but consists of articular cartilage and synovial fluid. Cartilage is of the same radiodensity as the soft tissues and, therefore, is not visualized as such, only the space between the adjacent articular cortices can be appreciated. This distruction of articular cartilage leads to joint space narrowing).

Erosions developes but less frequent in knee. (Erosions - Erosion is an area of destruction of the articular cortex and the adjacent trabecular bone). The process may progress to destruction of major portions of the articular cortex. Pseudocysts, which occasionally are quite large, may form in later stages. Secondary eburnation of the subarticular cortex may result. Sparse, thin periosteal new bone formation may be seen, particularly at the distal femoral metaphyses. Osteophytes are also developed after the development of secondary osteoarthritis (Osteophytes - Osteophytes are bony spurs, which may be quite large, occurring at the articular margins on both sides of the joint).

\section{OBSERVATION}

1. For the fulfillment of the present study, the Amavata disease has been studied radiologically with clinical manifestation of Vrushchika Danshavata Vedana, Sandhishotha, Stabhdata, Angamarda, Aruchi, Trushna, Alasya, Gaurava, Jwara, Apaka, Angashootha, these symptoms are similar to that of Rheumatoid arthritis.

2. The 7 diagnostic criteria according to American College of Rheumatology, epidemiology and genetics, radiological evaluation is one of them, for knee joint- soft tissue swelling, periarticular osteoporosis, joint space reduction, osteophytes, 
dislocation of joints, secondary eburnation, pseudocytes, periosteal new bone formation, bone erosion is seen.

3. It is been observed that $80 \%$ of patients affected with Amavata is found to be females and especially of $41-50$ years age group. Also the people of Vata-Kapha Prakruti are more affected or prone to Amavata.

4. In radiological changes, soft tissue swelling, joint space reduction and osteophytes is found in $80 \%$ patients, periarticular osteoporosis is found in almost $90 \%$ patient.

\section{CONCLUSION}

In radiological investigation (X-ray) of knee joints affected by Amavata, the radiological changes found are- soft tissue swelling, periarticular osteoporosis, joint space reduction, osteophytes, dislocation of joints, secondary eburnation, pseudocytes, periosteal new bone formation, bone erosion. Female are more prone to radiological changes in knee joint affected by Amavata than male. Also age group of 41-50 yrs are more affected and Vata-Kapha Dehaj Prakruti people has more radiological changes. This is helpful to find out the extent of progression of disease in stages of disease and treatment of disease.

\section{REFERENCES}

1. Sharangdhar Samhita, Purva Khanda 5/ 56,57, Kaladikakhyanam, page no. 43,44, Sharangdhar Samhita by Dr. Bramhanand Tripathi, Chaukhamba Surabharti Prakashan, Varanasi, Edition 2016

2. Sushrut Sharir Sthan 5/ 28, Sharirsankhyavyakaran Sharir adhyaya, pg.no. 80, Sushrut Samhita by Dr. Anantaram Sharma, Chaukhamba Surabharti Prakashan, Varanasi, Edition 2017

3. Sushrut Sharir Sthan 5/ 27, Sharirsankhyavyakaran Sharir adhyaya, pg.no. 79, Sushrut Samhita by Dr.
Anantaram Sharma, Chaukhamba Surabharti Prakashan, Varanasi, Edition 2017

4. Madhav Nidan 25/7, Amavatanidanam, Pg No. 511, madhav Nidan by Shri. Sudarshan Shastri, Chaukhambha Prakashan, Varanasi, 2017

5. Charak Sharir Sthan 7/ 6, Sharirsankhyashariradhyay, pg. no. 764, Charak Samhita by Ach. Priy Vrata Sharma, Chaukhamba Sanskrit Pratishthan, Delhi, Edition 2011

6. Ashtang Sangraha Sharir sthan 5/ 70, Atha Anga vibhag adhyaya, pg. no. 306, Ashtanga Sangraha by Dr. Shivprasad Sharma, Chaukhamba Sanskrit Series Office, Varanasi, $4^{\text {th }}$ Edition, 2016

7. Charak Sharir Sthan 7/ 6, Sharirsankhyashariradhyay, pg. no. 764, Charak Samhita by Ach. Priy Vrata Sharma, Chaukhamba Sanskrit Pratishthan, Delhi, Edition 2011

8. Kashyap Sharir Sthan, Sharirvischaya Shariradhyay, pg.no. 75, Kashyap Samhita by Ayurvedalankar Shri Satyapal Bhishagacharya, Chaukhambha Sanskrut Sansthan, Varanasi, Edition $4^{\text {th }}, 1988$

9. Ashtang Hriday Sutra Sthan 13/ 27, Doshopkramaniya adhyaya, Pg. no. 188, Ashtanga Hridayam by Dr. Bramhananda Tripathi, Chaukhamba Sanskrit Pratishthan, Delhi, Edition 2015

10. Harrison's Principles of Internal Medicine, Dr. Faufi, Dr. Braunwald, Dr. Wilson, Mc Graw Hill Medicine Publishing Division, Edition 15th

11. Radiology of Bone Diseases, George B Greenfield, Library of Congress Catloging in Publication Data, Edition $4^{\text {th }}, 1986$

How to cite this article: Wasu Isha Pradeep, Choudhari Vinod Mahadevrao. A study of Radiological changes in Janu Sandhi in Amavata. J Ayurveda Integr Med Sci 2020;1:22-25.

http://dx.doi.org/10.21760/jaims.5.1.5

Source of Support: Nil, Conflict of Interest: None declared.

Copyright (C) 2020 The Author(s); Published by Maharshi Charaka Ayurveda Organization, Vijayapur (Regd). This is an open-access article distributed under the terms of the Creative Commons Attribution License (http://creativecommons.org/licenses/by/4.0), which permits unrestricted use, distribution, and reproduction in any medium, provided the original work is properly cited. 